\title{
A Survey on the Objective of the Firm and Models of Producer Behavior in the Islamic Framework
}

\author{
Selamah Abdullah Yusof and Ruzita Mohammad Amin* \\ selamah@iiu.edu.my_ruzita@iiu.edu.my
}

\begin{abstract}
This paper presents a review of related works that have been written over the years on the objective of the firm from the Islamic perspective. For the purpose of analysis, a general framework on proper economic conduct and objective of economic order as discussed by al-Ghazali and Maududi, respectively is provided. Several studies that provide mathematical models to explain the producer behavior are further examined in a separate section. Our analysis finds that, in general, the arguments provided in justifying the objective of the firm as found in the various studies have the Islamic framework in mind. The theoretical models that have been developed can be used as a basis to formulate a more comprehensive model on Islamic producer behavior that provides more rigor and robustness to the analysis.
\end{abstract}

\section{Introduction}

In discussing producer behavior, it is necessary to first understand the ultimate objective of the producer. Scholars have stated a general objective that firms should produce goods and services which enable human beings to live a dignified existence in accordance with the requirement of their status as vicegerents of Allah (e.g. Chapra, 1984). There is a general opinion that the attainment of falah should be the ultimate goal of a producer as an Islamic economic agent (Sattar, 1988; Abbas, 1995; Siddiqi, 1979). Sattar (1988), for instance, describes falah as the achievement of well-being in the present world and the Hereafter, while Abbas explains falah as material and spiritual felicity where the goal is for the attainment of social bliss as well as spiritual salvation.

Siddiqi (1979) states that economic ends are always subservient to life ends and describes what it means by falah. According to him, falah is a comprehensive term denoting all-sided welfare of this life as well as that of the Hereafter. He also distinguishes between 'the pleasure of the Lord' and falah. While pleasure of the Lord

Associate Professors, Department of Economics, Kulliyyah of Economics and Management Sciences, International Islamic University Malaysia. 
is an abstract idea and beyond scientific analysis, falah is a tangible quality which can be 'understood' and as such forms the only means through which the achievement of the Lord's Pleasure can be ascertained and observed. While Pleasure is an act of 'will', bestowal of falah is the unfailing manifestation of that will. Siddiqi also cautions against confusing falah with the term 'welfare'. He refers falah to the good of both the worlds, whereas 'welfare' refers mainly to material wellbeing, or at best to the all-sided wellbeing of this world only. Falah implies that achievement of material wellbeing should be in a manner consistent with the achievement of welfare in the more important and eternal phase of human life-the Hereafter.

Given the ultimate objective of the producer as stated above, i.e., falah, there is a need to have a framework that provides the rules for proper economic conduct. Al-Ghazali lays down three principles which he considers of fundamental importance, namely, fair dealing, justice and beneficence/benevolence. Knowledge need to be acquired in order to discriminate between fair and unfair dealings, as well as to understand what is meant by justice in dealing with other fellow beings. Justice demands that a person should not act against the interest of a fellow Muslim. In making a livelihood, an individual earns money to sustain his bare existence and any extra earning is justifiable only when it helps others to realize the aims of religion (Umaruddin, 1970). Al-Ghazali defines benevolence as "an act which benefits persons other than those from whom the act proceeds without any obligation" (Umaruddin, 1970, p. 241). In other words, it is an act of helping others without expecting any return whatsoever.

In addition to the above framework, the objectives of the Islamic economic order presented by Maududi (1984) can also be applied as additional guiding principles. The first and foremost objective is to preserve individual freedom and to circumscribe it to such extent only as is compatible with the common good of humanity. Islam gives the maximum freedom of economic activity to the individual, binding him only to such limits as are really necessary for safeguarding the common good of humanity. The second objective is the moral development of man where each individual in the society should have the optimal opportunity to practice voluntary charity so that sentiments of generosity, sympathy, kindness and other moral virtues may become a living force in society. The third and last objective is to uphold human unity and brotherhood and oppose discord and conflict, hence promoting cooperation amongst individuals.

Thus, taking into account the ultimate objective of the Islamic producer and the framework that have been presented, the next section provides a review of works done in this area. In the same section, an attempt is also made to evaluate whether the objective of the firm ${ }^{1}$ stated in the works is consistent with the Islamic guidelines as described in the framework. ${ }^{2}$ In the course of the review, several studies have been found to provide mathematical models to explain the producer behavior, which warrants a separate discussion. This is provided in section 3, while the last section concludes.

(1) There may be several interpretations of what a 'firm' is, however, in this paper and as given in the works surveyed, the 'firm' is as defined in conventional economics in its neoclassical version.

(2) This study specifically focuses on the objective of the firm. There are other issues related to producer behavior such as cooperation versus competition and characteristics of a Muslim producer, which are beyond the scope of this paper but warrant further research. For further insight on these issues, see Akhtar (1992) and Mirakhor (2000). 


\section{Objective of the firm}

Siddiqi $(1979,1992)$ attempts to rationalize the Islamic producer behavior in the context of the objective of the firm. In conformity with al-Ghazzali's principles, Siddiqi states that a Muslim entrepreneur who is equipped with the knowledge and Islamic values will be inclined to live up to the Islamic ideals of justice and benevolence. Thus, the main aspects of business motivation in Islam are full compliance with the Islamic concept of justice and an urge to serve the society which makes the entrepreneur take the welfare of others into consideration when he makes his entrepreneurial decisions. $\mathrm{He}$ is of the view that while the demands of justice are to a large extent determinate, those of benevolence know no bounds.

While Al-Ghazzali presents only the general concepts of justice and benevolence, Siddiqi (1979) provides a more detailed elaboration on the two concepts. Justice, according to Siddiqi, implies balance, proportionality and harmony as much as it implies legal justice and rendering to each what is his due, i.e., rights. Justice requires that any injury to anybody should not be caused unless required by justice itself. Benevolence implies good behavior, generous dealings, sympathetic attitude, tolerance, humane and kind approach, mutual consideration and regard of one another's interest; rendering to others even something more than their due right, and contenting oneself with even something less than one's own due right. While justice demands right measures, benevolence exhorts upon measure inclined favorably towards the other party.

Keeping in mind the framework as set above, we found that there are different views that are put forth as to the specific objective of an Islamic producer or firm. One view is that firms strive to attain satisfactory level of profits. According to Zaim (1979), the objective of a firm is to have a reasonable profit plus just wages and price, and welfare. Similarly, Abbas (1995) and Siddiqi (1979) argue that the pursuit of falah suggests satisficing as a basis for the Islamic theory of the firm. Siddiqi's definition of satisfactory profits is presented in the context of justice and benevolence, and related to profit maximization within the limits set by the Islamic spirit. Hence, it will be elaborated further in the later part of this section where profit maximization is discussed.

In other studies, it is stated that the objective of the firm is to maximize utility as in Kahf (1978), Gusau (1988), Metwally (1992, 1997), Bendjilali and Taher (1990), Hallaq (1995) and Al-Safar (1998), or to maximize welfare as in Naqvi (1997). For Kahf (1978) and Gusau (1988), utility comprises of profit both in this world and the Hereafter. In addition, Gusau views that a meager profit margin in terms of material gains may well be all that an Islamic producer requires to retain him in business since he believes that he may be gaining an immense profit in the life after death. However, he added that an Islamic rational producer would leave a reasonable margin of material profit to maintain himself, his family and his business. In contrast to Siddiqi (1979), Naqvi's (1997) definition of welfare includes 'materialistic' welfare as well as spiritual satisfaction that flows from altruistic work done to gain Allah's approval. Although Naqvi uses the term 'welfare' instead of utility, there seems to be similarity between Naqvi's welfare and Kahf's and Gusau's utility. 
Metwally (1992, 1997), Bendjilali and Taher (1990), Hallaq (1995) and Al-Safar (1998) construct mathematical models where the objective of the firm is to maximize utility. In Metwally $(1992,1997)$ and Al-Safar (1995), utility is a function of profit and amount spent on charity. For Hallaq (1995) and Bendjilali and Taher (1990), utility is stated as a function of profit and welfare, where welfare is a function of output.

It is observed that most of the works that state utility or welfare maximization as the objective of the firm implicitly assume that there is a trade-off between gain to the firm or producer (profit) and gain to the society (in terms of charity, higher output or other altruistic works). A higher (lower) gain to the society can only be attained with a lower (higher) profit. This is a possible point of contention. While this may be obvious in Metwally (1992, 1997) and Bendjilali and Taher (1990), in Hallaq's (1995) model this trade-off may not necessarily take place since a higher profit implies a higher amount of charity, thus a higher gain to society. In addition, the assumption that welfare gains can only be achieved through higher output level as in Bendjilali and Taher (1990) or through an amount of charity which is fixed at the outset as in Metwally $(1992,1997)$ is somewhat restrictive. This is because welfare gains can also be obtained through at least two other means. Firstly, from zakah collected on profits which is incorporated in Metwally's $(1992,1997)$ model but is somehow not considered by Metwally as part of a gain to society. Secondly, having higher profit will motivate other firms to enter the market, thus providing more competition, and perhaps promoting higher R\&D which can lead to higher efficiency and improved welfare of the society.

Instead of satisfactory profit or maximization of utility, several scholars maintain that maximization of output should be the objective of a firm. This view is held by AlFaruqi (1983), Akhtar (1993) and Ali (1980). Akhtar (1993) maintains that producing the greatest level of output from the given input will ensure the optimum output for the economy, while Ali (1980) argues that it will bring about a sense of security and satisfaction to the human society. This stance, however, seems to be rather simplistic because more does not necessarily mean better. There are other factors that need to be taken into account, such as the type of good that is to be produced. It may well be true for a necessity good, but not necessarily for a luxury good. However, even for a necessity good, it still depends on how much of it has already been produced in the economy.

A view on the objective of a firm shared by many scholars is maximization of profits. For instance, Mohd. Amin and Abdullah Yusof (2003) demonstrate that if the firm takes into account the nature of the good to be produced in its valuation of opportunity cost, the profit maximization principle can still be applied in an Islamic economic framework to obtain allocative efficiency. In another study, Hassan (1992) argues that firms should strive for profit maximization. Profit, which is defined as the net (of depreciation) value product minus the minimum maintenance wage given to workers, should be shared between labor and capital on some agreed equitable basis. By doing this, it would ensure that it is free of exploitation, discontentment and strife.

The profit maximization hypothesis conforms to the Islamic concept of profitmaking in the case of competitive and monopolistic competitive firms according to Ariff (1997) and Arief (1982). In these cases, profit-maximizing behavior ensures that 
resources are allocated efficiently. Furthermore, the maximum profits attained in the long-run are just the normal profits. On the contrary, in cases when "abnormal" or "supernormal" profits are made, profit maximization is said to run counter to the Islamic stance. Ariff (1997) stresses the fact that what is more important is how profits are maximized, and what goes into the cost and revenue schedules. For example, misleading advertisements which raise revenue, and externalization of pollution costs which pushes down cost, are not acceptable in Islam. This point raised by Ariff is significant since he emphasizes individual freedom of the producer in his production decisions while at the same time stressing on the importance of the principles of fair dealing, justice and benevolence in his economic conduct.

In other studies where the firm is said to maximize profit, constraints are addedsome general, others, specific - to this objective. For example, Naqvi (1981) states that individual producers are free to maximize profits in an Islamic economy only under these modifications: (i) no excessive profits and keeping al-Adl between the relative shares of wages and profits; (ii) the markets that lead to excessive profits must be rejected; (iii) increasing the ratio of public to private goods particularly in poorer countries; and (iv) the consumption basket must heavily contain "wage-goods" and strictly exclude prohibited goods. In a similar vein, Dar (1988) maintains that profit motive is allowed, but not exaggerated profits. Iqbal (1992) also opines that the major objective of a firm is profit maximization, and added that if the firm is motivated by the Islamic morality, it will have some consideration for others. He also stressed on the importance of taking into account the contractual agreements and responsibilities governing the relationship of the owners of various factors of production in determining the behavior of a firm.

As mentioned earlier in this section, Siddiqi (1979) asserts that the ultimate objective of producers is falah. He argues that Muslim entrepreneurs may seek to maximize profits within the limits set by the Islamic spirit. The limits incorporate the Islamic ideals of justice and benevolence in which entrepreneurs are motivated by fully complying with the idea of justice and the urge to serve the society. In this case, the firm may want to attain satisfactory profit instead of maximum profit, which is any level of profit between an upper and lower limit, which satisfies the entrepreneur's sense of goodness as well as his urge to earn money, maintain and develop his enterprise and keep it in the good books of the customers, the government and the people in general. The upper limit is the level of profit of which it is maximized while the lower limit is defined as a level beyond which the entrepreneur is not expected to sacrifice his own interests for the welfare of others. It is the minimum profit which the entrepreneur would normally tend to stick to in case of a competition between benevolence and prudence.

In another study, although Kahf (1978) maintains that producers' objective is to maximize utility, profit maximization can be used as a fair approximation if it is looked at as constrained not only by cost but also by a minimum level of goodness guaranteed by both ethical values and legislation. Nevertheless, he concludes that producers will not be maximizing their profits if, and when, they feel that by lowering their profit margin they can further the good of the society thus be contented with satisfactory profits. 
In general, it is found that the arguments provided in justifying the objective of the firm as found in the various studies have been developed with the Islamic framework set in mind. They are found to be in conformity with the principles of fair dealing, justice and benevolence as given by al-Ghazali (Umaruddin, 1970) and the guiding principles of the Islamic economic order as presented by Maududi (1984). All the studies explicitly incorporate these principles into their propositions on the objective of the Islamic firm, with the exception of Ariff (1997) who assumes that these principles are implicitly imbued in the producer's ethical behavior in the usual process of maximizing profits under the assumption of perfect competition or monopolistic competition.

\section{Theoretical Models}

Based on the earlier discussion, we found that only five papers attempt to formalize the behavior of an Islamic firm in a theoretical framework. In this section, we will focus on these studies by presenting each of the models and providing further analysis and comments.

We first start with Metwally $(1992,1997)$ who describes an Islamic firm as one that would seek the maximization of utility which is a function of the amount of profits and the amount of spending on charity or good deeds. However, the amount of profit would, after the payment of all imposed taxes (zakah and other dues) be no less than a minimum level which is "safe" to keep the firm in business. Thus, the optimization problem is stated as follows:

Maximize utility, $U=U\left(\pi_{n e t}, G\right)$ subject to $\pi_{n e t} \geq \underline{\pi}$, where $\pi_{n e t}$ is net profit, $\underline{\pi}$ is a minimum level of profit which is 'safe' to keep the firm in business and $G$ is the amount spent on charity. Profit $(\pi)$ is obtained by deducting both total cost $(C)$ and the amount spent on charity from total revenue $(R)$.

$$
\text { Profit, } \begin{aligned}
\pi & =R(q)-C(q)-G \\
\pi_{n e t} & =\pi-(\text { amount paid on zakat })-(\text { additional dues paid on profit }) \\
& =\pi-\mu \pi-\beta \pi \\
& =(1-\mu-\beta) \pi \\
& =(1-\mu-\beta)(R(q)-C(q)-G)
\end{aligned}
$$

where $q$ is output, $\mu$ and $\beta$ are rate of zakat and rate of additional dues on profits, respectively.

In addition, Metwally states that spending on charity or good deeds in a society which whole-heartedly believes in it as the means to achieve God's satisfaction creates goodwill for the firm's product which in turn helps increase the demand for them at given prices. Thus, $\frac{d p}{d G}>0$, where $p$ is price of the product.

From the model he derives the optimal output for utility maximization to be at the level where marginal revenue equals marginal cost. However, he argues that since revenue is implicitly a function of charity, an Islamic firm with a similar cost structure as that of a non-Islamic firm will not have the same, but a higher equilibrium output and price. 
Several points can be highlighted from the model. Firstly, if spending on charity creates goodwill for the firm's products which in turn helps increase the demand for them at given prices, should it not be $\frac{d q}{d G}>0$, instead of $\frac{d p}{d G}>0$ ? Despite this, the outcomes will not be qualitatively different. More importantly, however, the assumption that charity affects revenue (through price or quantity) will result in not only higher output but also price level. This would bring to question the effect of the firm's good deeds on the net welfare of the society. While on the one hand the firm will be able to produce more of the good, which may not necessarily mean better, ${ }^{3}$ consumers will have to pay a higher price for the good. The result of a higher price is not unexpected since charity is assumed to affect demand. This can only happen if the act of charity is made known to the public. Thus, another question that may arise is the intention of the firm in spending on charity.

There is another possible outcome that can be obtained from the first order condition of the optimization problem which was not stated in the paper. This outcome is where the optimal level of output corresponds to the output at the minimum level of profit which is 'safe' to keep the firm in business. A situation like this can take place if the firm places a very high importance to charity relative to profit to the extent that the firm is satisfied by just having the minimum level of profit set.

The work by Al-Safar (1998) proposes a model using nonlinear programming in deriving the equilibrium of an Islamic firm. However, the model presented is found to be an exact reproduction of Metwally's (1992) model. Thus, Al-Safar's paper does not provide any additional contribution to the literature.

According to Bendjilali and Taher (1990), a single seller is expected to be concerned about the social welfare and therefore be willing to partially sacrifice his profits in order to attain efficiency and minimize social welfare loss. It is claimed that such behavior would lead to the best solution under monopoly conditions.

In developing the model, Bendjilali and Taher consider the case of a monopolist producing a necessary good. The firm is assumed to maximize utility, $U=U(\pi, w)$ subject to $\pi=R(q)-C(q)$, where $\pi$ is profit, $w$ is society's welfare gain, $R$ and $C$ are revenue and cost, respectively, which are functions of output, $q$. Since it is assumed that $w=w(q), \quad w^{\prime}>0$, thus the optimization problem can be written as:

$$
\begin{aligned}
& \underset{\pi, q}{\operatorname{Max}} U=U(\pi, q) \quad \text { subject to } \pi=R(q)-C(q) \\
& \text { where } U_{\pi}, U_{q}, U_{\pi q}, U_{q \pi}>0
\end{aligned}
$$

The outcome of the model shows that if the firm derives utility only from profit ( $U_{q}=0$, therefore the marginal rate of substitution of output for profit, $M R S_{q, \pi}=0$ ), the optimal output will be equal to the profit-maximizing level. However, if a firm's

(3) Refer to the subsequent discussion on Mohd. Amin, Ruzita, and Selamah Abdullah Yusof (2003). "Allocative Efficiency of Profit Maximization: An Islamic Perspective.” Review of Islamic Economics 13: 5-22. 
utility is positively affected by the level of production $\left(U_{q}>0\right)$, then the utilitymaximizing level of output will be greater than the profit-maximizing output. This implies that if the firm is concerned about social welfare, and higher output implies higher welfare $\left(w^{\prime}(q)>0\right)$, then the firm is willing to sacrifice some of his profits for an output level higher than the profit-maximizing level, hence providing more benefit to the society.

In addition, the authors derive the condition for the firm to produce at the (allocative) efficiency level, i.e., the marginal rate of substitution of output for profit, $M R S_{q, \pi}=-p^{\prime}\left(q_{e}\right) q_{e}$ where $p(q)$ is the inverse demand function and $q_{e}$ is the level of output where marginal cost equals to price. However, they provide no further elaboration nor discuss the implications of the results.

Bendjilali and Taher provide a simple yet clear illustration of how allocative inefficiency can be reduced in monopoly if the firm takes into account the welfare of society in its choice of output level. However, it does not necessarily imply that allocative efficiency will be achieved (i.e., zero efficiency loss) since the restrictive condition for such efficiency as stated earlier may not necessarily be fulfilled. The model only predicts that output will be at a level greater than the profit-maximizing but not necessarily equal to the utility-maximizing point, depending upon the preference of the firm towards profit and output.

We find that we can extend Bendjilali and Taher's analysis to include other possibilities. As mentioned by Bendjilali and Taher, one possible outcome is that output will be at the profit-maximizing level. This is an extreme case where the firm's utility is determined solely by profit. In cases where both output and profit are determinants of the firm's utility function, the optimal level of output depends on the preference that the firm places on output relative to profit. The higher the relative preference towards output, the higher will be the optimal output which can even be higher than the level at which allocative efficiency is achieved (price equals to marginal cost). As shown in Figure (1), a firm with a higher relative preference towards output implies one having a "steeper" indifference curve such as $U_{e}$ or $U_{o}$ rather than $U_{a}^{1}$. Thus, a firm may end up with an output level of $q_{e}$, the allocative efficiency level, or even $q_{o}\left(>q_{e}\right)$.

Bendjilali and Taher's analysis is confined to the case of necessary goods only. A possible area of further research is to extend the model to include other types of goods as well as other market structures.

Hallaq's (1995) work appears to be an attempt to incorporate both Bendjilali and Taher's (1990) and Metwally's (1992) models into one. Similar to Bendjilali and Taher, Hallaq starts with the premise that the behavior of a Muslim firm is expected to differ from that of a non-Muslim firm due to the differences in their objectives. His paper seeks to address the question of how concern for the good of the society would influence a firm's output decision. 

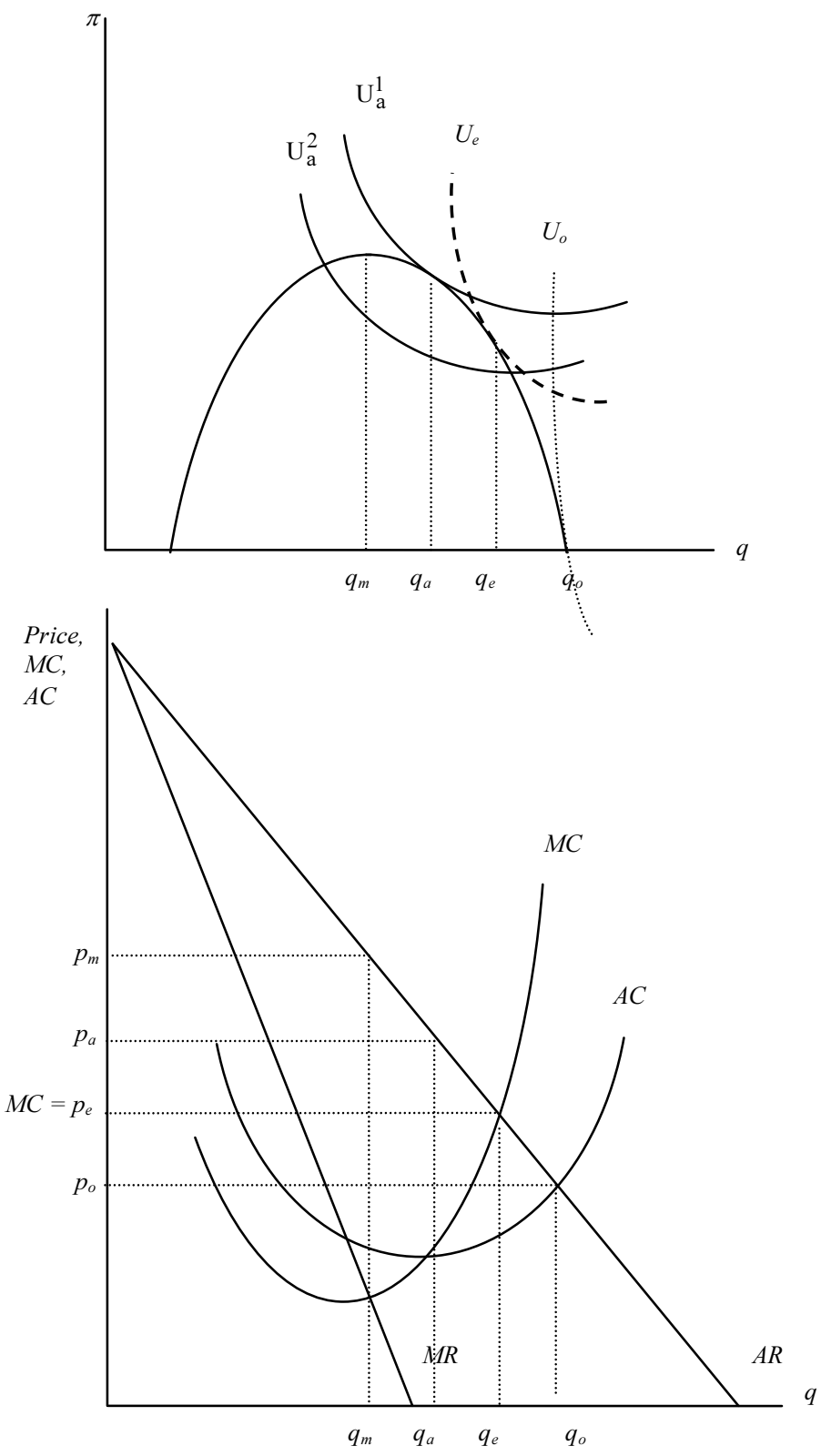

Figure (1). Utility Maximizing Points at Various Preferences Between Profit and Output. 
As in Bendjilali and Taher, Hallaq considers the case of a firm producing necessary goods. The concern for social welfare is incorporated in two ways. Firstly, the utility of a firm is a function of both profit and output, since it is assumed that social welfare increases with output level. Secondly, the Muslim producer also spends on charity as contribution to social welfare. This is similar to Metwally's (1992) model. However, while Metwally assumes charity $(G)$ to be independent of other variables, Hallaq (1995) specifies spending on charity to be a function of the profit $(\pi)$ obtained, specifically, $G=\alpha \pi$, where $0 \leq \alpha \leq 1$ and $\alpha$ denotes the degree of faith the Muslim producer possesses. Thus, social welfare can be increased through a higher level of output or through a higher level of profit, or both.

The objective of the firm is thus to maximize utility, $U=U(\pi, w)$ where $\pi$ is profit, and $w$ measures society's welfare gain. It is assumed that $w=w(q), w^{\prime}>0$, where $q$ is output, thus the optimization problem can be written as:

$$
\underset{\pi, q}{\operatorname{Max}} U=U(\pi, q) \quad \text { subject to } \pi=R(q)-C(q)-G \text { or } \pi=(1-\alpha)(R(q)-C(q))
$$

From his model, Hallaq argues that if $\alpha=0$ (implying the degree of faith is zero), the profit-maximizing output level will be the same as that of conventional firm. However, this result is not true since as shown by Bendjilali and Taher (1990) a firm will produce an output level greater than the profit-maximizing level as long as the firm attaches importance to output in its utility function. Hallaq also states that since the average cost of the Muslim producer is higher than that of the non-Muslim producer due to the incorporation of charity, the profit attained by the Muslim producer will be lower. However this is inaccurate since charity is a function of profit as stated earlier by the author ( $G=\alpha \pi$ ), and thus cannot be a function of cost. The average cost will not differ between the two firms. In addition, $\alpha=0$ implies that good deeds to the society (welfare effects) are solely in the form of higher production of the necessary goods.

We can obtain another result from Hallaq's model, that is for the other extreme case when $\alpha=1$. In this case all profits are given to charity. From the first-order conditions, the marginal utility of output will then be zero. This means that the firm transfers all the profits to the society in the form of charity, therefore it would want to gain as much profit as possible without regard to the final outcome on the level of output. In this case, depending on how the amount of charity is distributed, the consumers of the goods may not necessarily be the beneficiaries.

In contrast to the earlier models which assume utility maximization by firms, Mohd. Amin and Abdullah Yusof (2003) contend that profit maximization is valid for an Islamic economic framework to achieve the desired outcome of an Islamic economy in terms of producing the 'right' goods in the 'right' amounts. They argue that it can be achieved if in the valuation of its opportunity cost the firm takes into account the nature of the good to be produced, in accordance with Islamic ethical values. The opportunity cost or the value of the best alternative good will depend on its position in the hierarchy of goods. For instance, in the production of a necessity good which has a high 
mas laúaú (giving high benefit or value to the society), ${ }^{4}$ where its best alternative is to produce a refinement good which has a relatively lower maslaúaú (giving lower benefit or value to the society), the opportunity cost of producing the necessity good will be lower. On the other hand, in the production of a refinement good of which the next best alternative is a necessity, the opportunity cost of producing the refinement good will be higher. Therefore the implicit cost component of the cost function of an Islamic firm will differ from the conventional.

The optimization problem can be stated as follows:

Maximize profit, $\pi=\pi(q)=R(q)-C(q)$, where $R$ and $C$ are revenue and cost, respectively, which are functions of output, $q$. The cost function is defined as $C(q)=E(q)+I(q)$, where $E$ is explicit cost and $I$ is the implicit cost. For the conventional firm, $I(q)=I_{c}(q), I_{c}(0)=0$, while for the Islamic firm, $I(q)=I_{C}(q)+\alpha(q), \quad \alpha(0)=0$, where $\alpha$ is the Islamic valuation of opportunity cost of the good based on maslaúaú. The authors assume that if the good produced is a necessity, $\alpha^{\prime}(q)<0$ for $q>0$, since the higher is the production of the necessity good (i.e., the higher the fulfillment of the society's needs), the smaller is the opportunity cost associated with its production. Alternatively, if the good produced is a refinement, $\alpha^{\prime}(q)>0$ for $q>0$.

The model predicts that the production of necessity goods will be higher and the price is lower for the Islamic firm compared to that of the conventional firms. On the other hand, an Islamic firm will produce a lower level of refinement goods at a higher price. Hence, incorporation of Islamic values by profit-maximizing firms in the valuation of opportunity cost can ensure a better allocation of resources with respect to the hierarchy of needs of the society.

The paper provides a simple model which can be applied to predict outcomes for different 'types' of goods, i.e., necessities, conveniences and refinements. In their concluding remarks, the authors suggest certain policy measures that could be carried out to achieve the desired outcomes However, the suggestions given such as imposing taxes on refinement goods and providing subsidies on necessity goods to internalize the social costs or benefits into the cost structure of the firm calls for state intervention for implementation of these policies.

\section{Conclusion}

This study presents a review of works done in the area of producer behavior, specifically looking at the objective of the firm from the Islamic perspective. The review is undertaken in the light of the ultimate objective of the producer of achieving falah, which is the well-being in the present world and the Hereafter. The Islamic framework for proper economic conduct and the objectives of the Islamic economic order are also taken into account. Fair dealing, justice and benevolence form the rules of

(4) The study assumes that the economy has yet to fulfill the needs of the society. Therefore, higher amounts of necessity goods produced is assumed to give higher benefit to the society as compared to refinement goods. 
proper economic conduct while the preservation of individual freedom compatible with the common good of humanity, optimal opportunity to practice voluntary charity to instill moral virtues as a living force in society, and the establishment of human unity and brotherhood to promote cooperation present the objectives of the Islamic economic order that serve as additional guiding principles in a Muslim's economic conduct.

All the works reviewed have been developed within the Islamic framework set above. All the studies attempt to explicitly incorporate these principles in developing the arguments and models, with the exception of Ariff (1997) who assumes that these principles are implicitly imbued in the producer's ethical behavior. Although all these works are found to be in line with the Islamic framework outlined earlier in the paper, some arguments are found to be stronger, while others weaker, in presenting their cases. It has to be borne in mind that in the process of analyzing Islamic producer behavior in order to derive desired outcomes in an Islamic economic framework, the arguments presented need to be sound and not overly simplistic, in order for it to merit recognition and acceptance.

\section{References}

Abbas, Abdel Rahman B.M. (1995) "Islamic Economics: A Psycho-ethical Paradigm", Al-Ta'sil 2: 116-23.

Akhtar, M. Ramzan (1992) "An Islamic Framework for Employer-Employee Relationships", The American Journal of Islamic Social Sciences, 9(2): 202-18.

Akhtar, M. Ramzan (1993) "Modelling the Economic Growth of an Islamic Economy", The American Journal of Islamic Social Sciences, 10(4): 491-511.

Ali, Mohammad Yousuf (1980) "Optimal Utilization of Resources and Maximization of Production in Islam”, in Thoughts on Islamic Economics. Bangladesh: Islamic Economics Research Bureau: 218-27.

Arief, Mohamed (1982) "Ethics and Economics in Islam", Islamika 2: 97-113.

Ariff, Mohamed (1997) "The Role of the Market in the Islamic Paradigm", IIUM Journal of Economics and Management 5(2): 97-107.

Bendjilali, Boualem, and Farid B. Taher (1990) "A Zero Efficiency Loss Monopolist: An Islamic Perspective", The American Journal of Islamic Social Sciences, 7(1): 219-32.

Chapra, M. Umer (1984) "The Economic Problems of Man and Islam", Islamic Order 6: 17-31.

Dar, Muhmmad Ilyas (1988) "Islamic Economic System", Journal of Islamic Banking and Finance, 5(3): 37-51.

Gusau, Sule Ahmad (1988) "The Nature and Methodology of Islamic Economics", in Frontiers and Mechanics of Islamic Economics, Rafikul Islam Molla, Abdul Rashid Moten, Sule Ahmad Gusau and Abubakar Aliyu Gwandu (ed.) Nigeria: University of Sokoto.

al-Faruqi, Ismail Raji (1983) "Tawhid: The Principle of the Economic Order", Tawhid for Thought and Life, 1: 187-222.

Hallaq, Said (1995) "Rationality in Production: The Case of the Muslim Firm", Humanomics, 11 (4): 29-38.

Hassan, Zubair (1992) "Profit-maximization: Secular versus Islamic", in Readings in Microecomics: An Islamic Perspective, Syed Tahir, Aidit Ghazali and Syed Omar Syed Agil (ed.), Selangor, Malaysia: Longman.

Iqbal, Munawar (1992) "Organization of Production and Theory of Firm Behaviour from an Islamic Perspective," in Lectures on Islamic Economics, Ausaf Ahmad and Kazim Raza Awan (ed.). Jeddah: Islamic Research and Training Institute, IDB: 205-15.

Kahf, Monzer (1978) "The Theory of Production", in The Islamic Economy: Analytical Study of the Functioning of the Islamic Economic System, by Monzer Kahf. Plainfield, Indiana: The Muslim Students' Association of the United States and Canada: 29-38. 
Maududi, Syed Abul A'ala (1984) Economic System of Islam. Lahore, Pakistan: Islamic Publications Ltd.

Metwally, M.M. (1992) “A Behavioral Model of an Islamic Firm”, Readings in Microecomics: An Islamic Perspective, Syed Tahir, Aidit Ghazali and Syed Omar Syed Agil (ed.). Selangor, Malaysia: Longman.

Metwally, M.M. (1997) "Economic Consequences of Applying Islamic Principles in Muslim Societies", International Journal of Social Sciences, 24(7, 8, 9): 941-57.

Mirakhor, Abbas (2000) "General Characteristics of an Islamic Economic System", Anthology of Islamic Banking, Asma Siddiqi (ed.). London: Institute of Islamic Banking and Insurance.

Mohd. Amin, Ruzita, and Selamah Abdullah Yusof (2003) "Allocative Efficiency of Profit Maximization: An Islamic Perspective." Review of Islamic Economics, 13: 5-22.

Naqvi, Syed Nawab Haider (1981) "Economics of Human Rights: An Islamic Perspective." Hamdard Islamicus 4: 31-51

Naqvi, Syed Nawab Haider (1997) "The Dimensions of an Islamic Economic Model”, Islamic Economic Studies, 4(2): 1-24.

al-Safar, Abdul Kareem (1998) "Use of Non-linear Programming in Achieving Equilibrium of an Islamic Firm." Humanomics, 14(2): 74-89.

Sattar, Zaidi (1988) "The Ethics of Profit in the Islamic Economic System: A Socioeconomic Analysis", The Islamic Quarterly: A Review of Islamic Culture, 32(2): 69-76.

Siddiqi, Muhammad Nejatullah (1979) The Economic Enterprise in Islam, $2^{\text {nd }}$ edition, Lahore, Pakistan: Islamic Publications.

Siddiqi, Muhammad Nejatullah (1992) "Islamic Producer Behaviour", in Readings in Microecomics: An Islamic Perspective, Syed Tahir, Aidit Ghazali and Syed Omar Syed Agil (ed.). Selangor, Malaysia: Longman.

Umaruddin, M. (1970) The Ethical Philosophy of Al-Ghazzali. Lahore, Pakistan: Sh. Muhammad Ashraf.

Zaim, Sabah Eldin (1979) "Islamic Economics as a System based on Human Values", Journal of Islamic Banking and Finance, 6(2): 13-21. 


$$
\text { دراسة استطلاعية لمدف المنشأة ونماذج سلوك المنتج }
$$

$$
\begin{aligned}
& \text { سلامة عبدالله يوسف و روزيتا محمد أمين } \\
& \text { أستاذ مشارك - قسم الاقتصاد } \\
& \text { كلية الاقتصاد والعلوم الإدارية } \\
& \text { الجامعة الإسلامية العالمية بماليزيا }
\end{aligned}
$$

المستخلص. تقدم هذه الورقة مراجعة لأعمال علمية كتبت على هدى سنين عن هدف الثركة من منظور إسلامى. ورغبة في تحليل دقيق،

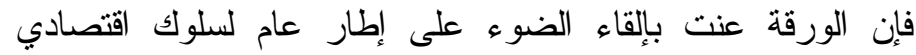

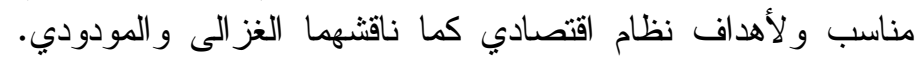

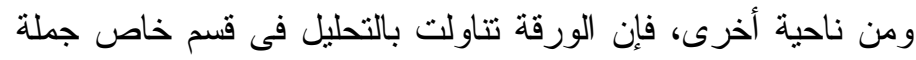

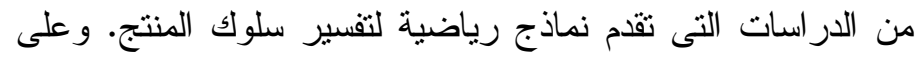

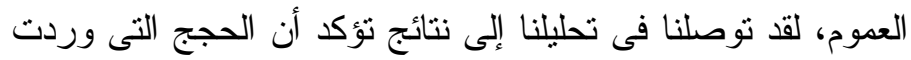

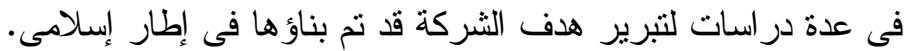

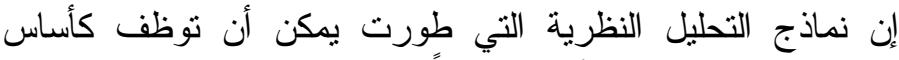

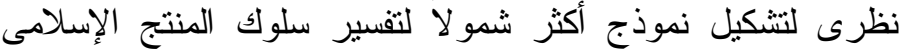
و المساعدة على نوفير دقة وفعالية أكبر للتحليل. 